\begin{tabular}{|c|c|c|c|}
\hline 曲 & First Received: 20 January 2018 & $\sqrt{\overline{E \Theta}}$ & Final Proof Received: 30 March 2018 \\
\hline
\end{tabular}

\title{
MATN CRITICISM AND ITS ROLE IN THE EVALUATION OF HADITH AUTHENTICITY
}

\author{
Ayub \\ Email : ayubdaud@gmail.com \\ School of Oriental and African Studies, University of London, London, UK
}

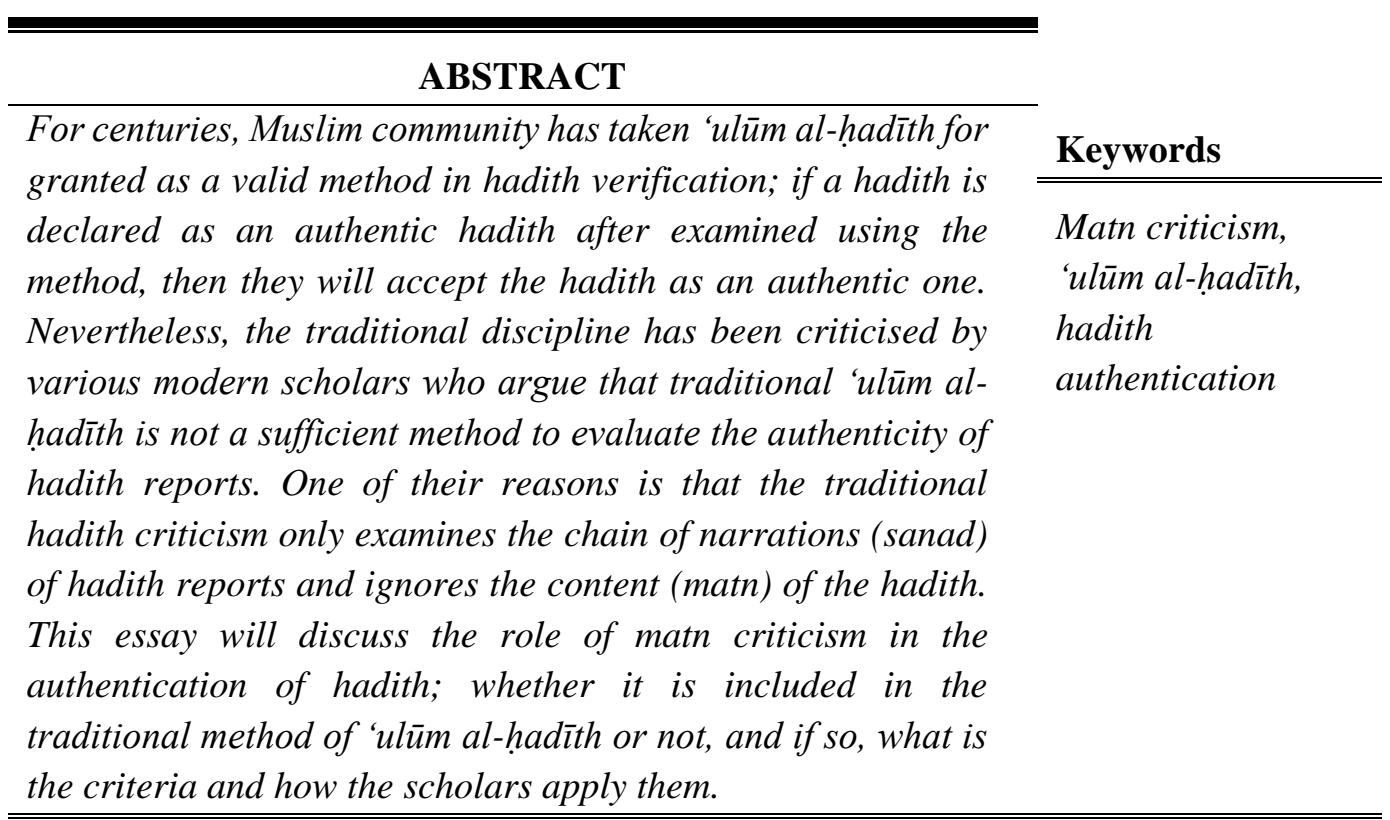

\section{INTRODUCTION}

Hadith is reports of the words, actions, tacit approvals or disapprovals of Prophet Muhammad. It is also called the Sunnah, which is the second source of Islamic teachings after the al-Qur'an. In fact, the detail aspects of Islamic law, theology, and morals are found in the hadith. However, unlike the al-Qur'an, not all hadith that exist and spread among Muslims are authentic. Therefore, Muslim scholars have developed a method to evaluate the authenticity of these reports. The method then matured into a formal discipline called 'ulüm al-hadìth, the science of hadith. Science then, the method has been recognized as a valid and effective way to scrutinize hadith narrations.

Unlike the Muslim community who have accepted 'ulüm al-hadith as an adequate method to authenticate hadith reports, Western scholars, understandably, have been very sceptical toward hadith literatures. As early as 1848, Gustav Weil had suggested that a substantial amount of hadith should be regarded as spurious (Hallaq, 1999: 75). It was Ignaz Goldziher and Joseph Schacht's theories that paved the way of critical study of the authenticity of hadith, especially after the publication of Schacht's The Origin of Muhammadan Jurisprudence in 1950 in which he argues that (legal) hadiths must be assumed unauthentic until the contrary is proven (Schacht, 1950: 1-4). Since then, many 
scholars, Western and Muslim alike, have proposed their theories on this topic. According to Hallaq, there are three main approaches in recent hadith scholarship; those who sought to reinforce Schacht's conclusions; those who seek a synthesis conclusion; and scholars that develop counter arguments against his thesis (Hallaq, 1999: 76). The scholars of first and second "camp" clearly do not consider traditional hadith criticism as an adequate method, therefore they consider many hadiths as unauthentic although they have been proven to be sahih according to traditional criteria.

Their main objection toward traditional hadith criticism is that the method is only concern aboutthe isna $\bar{a}$ of the hadith and proven to be inadequate when it comes to matn criticism. In Golziher's words, "The judgment of the value of thecontents depend on the judgment of the correctness of the isnäd (...) An impossible sentence full of inner and outer contradictions is appended withstands the scrutiny of this formal criticism, if the continuity of the entirely trustworthy authors cited in them is complete and if the possibility of their personal communication is established, the tradition is accepted as worthy of credit (...) Muslim critics have no feeling for even the crudest anachronisms provided that the isnād is correct" (Goldziher, 1971: 140-141). Following Goldziher, Schacht points out that the method employed Muslim scholars might have eliminated some forged hadiths but there are still considerable number of unauthentic hadiths in the cannon collections because the traditional method fails to recognize and eliminate those fake hadiths with often selfcontradiction contents. Schacht argues that the major shortcoming of traditional method that "Muhammadan scholars" employ is its invariably restricted to a purely formal criticism of isnād (Schacht, 1950: 3).

Critical discussion on matn criticism not only heated among Western scholars but also among modern Muslim intellectuals. Some of them also raise similar criticism toward traditional 'ulüm al-hadìth. Israr Ahmad Khan, for example, regards the overemphasizing on isnād in 'ulüm al-hadīth as "delusion of reliable narrators." He highlights the fact that whenever hadith commentators face a problematic matn, instead of examining the matn itself as a possible source of unreliability, they tend to blame the narrators, assuming that they had a misunderstanding or misconception about the matn (Khan, 2010: xix). Ahmad Amin, an Egyptian thinker points out that traditional hadith scholars pay more attention to the isnād than to the matn. Furthermore, Abū Rayyah even accused scholars of hadith of completely ignoring the essential content of hadith and failing to look at historical evidence (Amin, 2005: 262).

These accusations have been answered by many scholars, western and Muslim alike. Coulson regards Schacht's approach to be too narrow for he draws a general and radical claim based only on his analysis on legal hadith. While Coulson agrees with Schacht's conclusion about the unreliability of the isnād system, he argues that the substance of the hadith might reflect an authentic decision of the Prophet (Coulson, 1983: 321). Burton states that the complaint about overemphasizing on isnād among Muslim scholars is an overstatement. Burton provides an example of a hadith about female jin that was rejected by Muslim critics because of its illogical content. Burton says that "criticism of the matnis not so rare as it sometimes claimed" (Burton, 1994: 169). Abbot even argues that Muslims have employed content (matn) criticism to verify a hadith since the era of the Companions who frequently compared the matn of their hadith collections. The emphasis on isnād, she 
argues, only started after the period of the fitnah. Therefore, Abbot insists that the view that matn has been treated only as secondary to isnād as the basis of acceptability of hadith need to be modified (Nabia Abbot, 1967: 75).

Muslim scholars such as Muștafā al-Sibā' ‘̄̄, Muhammad Abū Shuhbah, and Nūr alDīn 'Itr argue that the emphasise on matn can be seen in the criteria laid down by the traditionists (muhaddithūn), in which they state that sound hadith must be free from shādh and 'illah. These two terms refer not only to isnād but also matn (Nabia Abbot, 1967: 75). Zubair cites al-Hākim al-Naysābūrī, one of the earliest author on 'ulūm al-hadìth, who says that sometimes hadith with sound isnād can be classified as a weak hadith. This indicates that al-Hākim far from only using isnād as solely standard of authenticity (Muhammad Zubair Shiddiqi, 1961: 113).

Scholars who argue that matn criticism has been employed in hadith criticism since early period of Islam often support their case by providing evidences of matn criticism conducted by early scholars. One of the famous example is ' $\overline{\mathrm{A}}$ 'isyah's rejection of Ibn 'Umar's hadith report that a dead relative would be punished for his family's excessive mourning because she believed that it violated the Qur'anic principle that 'no bearer of burdens bears the burdensof another'. However, these evidences are considered by Brown as not satisfactory, especially the evidence from the Companions for the lack of surviving documentary evidence of how they approached hadith criticism. According to Brwon's assessment, Luqmān al-Salafĩ and Ḥamzah al-Malībārī have been only two modern Muslim scholars that are able to provide substantial evidence for matn criticism from the early hadith tradition (Brown, 2008: 154).

Brown explains that early critics disguised their matn criticism by using the language of isnād criticism, therefore it is not easy to find the evidences (Brown, 2008: 143). Nonetheless, Brown manages to find examples of matn criticism in the works of early hadith critics that often thought to only employ isnäd criticism. There are 15 examples presented by Brown, 12 of them were conducted by hadith scholars of the third/ninth century; al-Bukhārī (d. 256/870), Muslim (d. 261/875), Ya'qūb ibn Sufyān al-Fasawī (d.277/890) and Ibrāhīm ibn Ya'qūb al-Jūzajānī (d. 259/873). The rest were conducted by critics who lived in fourth/tenth century, namely Muhammad ibn Isḥāq ibn Khuzaymah (d. 311/923) and Muḥammad ibn Ḥibbān al-Bustī (w. 354/965) (Brown, 2008: 154-162). Brown's findings prove that matn criticism has been utilized by early Muslim scholars. The next part of this artcle will discuss their practice.

\section{RESULTS AND DISCUSSION}

\section{Historical Development of Hadith Authentication}

The impetus behind the birth of "ulüm al-hadith was the wide spreading of hadith forgery. As described by Abbot, early hadith criticism conducted by Muslim scholars was "the angry reactions of Companions and early Followers (tābi 'ūn) to unscrupulous and careless circulators of illegitimate information about the Prophet" (Nabia Abbot, 1983: 287). That "angry reactions" eventually developed into a formal discipline known as "ulüm al-hadìth. Therefore, in order to understand the development of the discipline, including the role of matn criticism, one should pay attention to this historical context. Hadith fabrication can be traced to the early period of Islam. The murder of the third rightly-guided caliph Utsman 
was one of the fateful moment in Islamic history, the moment had triggered chain of tragic events including civil wars and formation of various theological sects. In their debate, these groups utilized hadith reports to support their theological and political stances, they even go as far as to fabricate hadith to support their case. Therefore, according to some historians, hadith forgery taken place for the first time around that time of political turmoil (fitnah) (J. A. Brown, 2009: 77). Reportedly, it was initially done by Ibn Saba' to promote the imamate of "Alī (Khan, 2010: xix). Al-'Umarī, on the other hand, argues that the first hadith fabricator was Ibn 'Adīs, who forged hadiths to condemn caliph 'Uthmān.

Apart from political motivations following the civil war, there are some other motives behind hadith forgery. Al-Nawawī mentions their reasons in his taqrīb, (and later on explained by al-Suyuțī) According to these towering scholars of hadith, the reasons behind hadith fabrication include; those devout figures who forged hadith to persuade people to be more pious such as Nūh al-Jamī' and propagandists of the al-Karamiyah , alNawawi states that this type of hadith fabricators are the most harmful; those who forge hadith to support their heretical sects; Ibn Șalāh also added, those who forged hadith to support their theological or legal schools (madhähib), those who fabricated hadiths to praise political rulers; and those who fabricated hadith to support their legal decisions .

The phenomenon of hadith fabrication had fostered Muslim scholars to develop a systematic intellectual tool to determine the quality of a hadith; whether it is an authentic report that originated from the Prophet himself or otherwise. According to traditional account accepted among Muslims, Ibn Sìrīn (d. 110), an influential scholar of the tābi 'inn generation, was reportedly said, "In the beginning they would not asked about isnād. But when the political turmoil happened, they demanded, 'Name your man to us.' The narrators of ahl al-sunnah would be accepted, while those who ahl al-bid 'ah would be rejected."This practice produce the branch of hadith science called al-jarh wa' $l$-ta 'dìl with main purpose to distinguish reliable narrators from the unreliable ones (Philips, 2007: 50).

From the narration of Ibn Sīrin it seems that the focus of scrutiny in the early period following the civil war was mainly on isnād. However, that is not the case. Citing alA'zamī, Ismail argue that isnād criticism was actually the outcome or findings of matn criticism by earlier scholars. A scholar would not able to ascertain the status of narrators in a chain of isna $\bar{d}$ unless they have studied the narrated texts of the hadith of the narrator in question. Narrators who adduced the matn of the hadith that is incongruous, contsxradictory and froth with mistakes would be regarded as not a very reliable narrator (Ismail, Baru, Hassan, Bin Salleh, \& Amin, 2014: 152). Thus, al-jarh wa'l-ta 'dìl which is the essential of sanad criticism cannot be separated from actifity of matn criticism conducted by earlier scholars.

\section{The Role of Matn Criticism}

Matn criticism of earlier scholars mainly conducted by method of comparison as stated by Ibn al-Mubārak (d. 181) a second century scholar, "To reach authentic statement one needs to compare the words of scholars with each other as well." The method of comparison was practiced in many ways, al-A 'zamī mentions some of them; 1) comparing between the hadith of different students of one scholar; 2) comparison between the statements of single scholar at different tmes; 3 ) comparison between oral recitation and written document and 
4) comparison between the hadith and related verse of the al-Qur'an (A'zamī, 1977: 52). After doing these procedure, a scholar of hadith will be able to determine not only the quality of a hadith but also the quality of its narrators. For example, Ibn Ma'īn (d. 233) was able to grade seventeen students of Ḥammād after their narrations (A'zamī, 1977: 53).

Along with al-jarh wa'l-ta'd $\bar{l}$ l, there is also a branch of hadith science called muștalāh al-hadìth (classification of hadith), which is a discipline concerning the evaluation of the hadith.The classification is initiated in "tounderstand and determine whether a hadith is accepted or rejected and explain the decision with itsjustifications" (Ismail et al., 2014: 152). The science of hadith has multiple branches, thereofe, al-Hākim al-Naysābūrī (d.450), the author of the one of earliest comprehensive works on hadith, named his book, Ma'rifah 'Ulüm al-Hadìth, (mastering the sciences of hadith) indicating that there are several branches in the discipline (Kamali, 2014: 8). After undergoing a process of scrutiny by mean of 'ulüm al-hadìth, the hadith would be classified as șahīh (sound), hasan (good), da 'îf (weak) and mawdī'(fabricated, forged) (Hasan, 1994: 8).

In the third/ninth century there was an emergence strong traditionalists opposition against the rationalists who tend to ignore the Sunnah and rely solely on human intellect in their ijtihād. Part of the impact of the traditionalist movement was increasing numbers of hadith compilations (Hallaq, 1999a: 21). Șah̄ịh of al-Bukhārī (d. 256/870) and Muslim (d. 261/875) were undoubtedly the most influential and reliable compilations, even until today. However, according to Brown, neither of these scholars lied down tangible criteria of hadith that they consider to be șahịh. He points out his finding that it was Ibn Khuzaymah (d. 311/923), one of Muslim's student, who leave the earliest surviving definition of sahịh. Ibn Khuzayma notes that he will not accept a hadith unless it a hadith that is narrated by an upstanding (' $a d l$ ) transmitter from another upstanding transmitter continuously to [the Prophet] without any break in the isnãd nor any impugning of the reports' transmitters (J. A. Brown, 2009: 271).

Nevertheless, Brown's explanation does not mean that Muslim or al-Bukhārī did not set any criteria. In fact. in his Șahīh, Muslim states that one should know how to differentiate between sound narrations and the weak ones. He then explains the criteria including the personality and integrity of the narrators in the isnād (Muslim, n.d., I: 8). Muslim's criteria of șahih also explicitly displayed in the complete title of his monumental work; “al-Musnad al-Ṣaḥ̄h al-Mukhtașar bi 'l-Naqli al- 'Adl 'an'l- 'adl ilä Rasülillāh.” Ibn Salah gave a more detailed definition of sahīh as he states that, "Șahịh is the one which has a continuous isna $\bar{d}$, made up of reportersof trustworthy ('adl) with good memory ( $d \bar{a} b i t$ ) from similar authorities, and which is found to be free from any irregularities (shädh) or defects ('illah)" (Ibn Șalāḥ, 2002: 79).

The last two criteria are not only applied to isnād but also to matn (Amin, 2005: 262). Later scholar would translate 'illah and shädh of matn in more tangible cirteria. In al-Kifāyah fì 'Ilm Ușūl al-Riwāyah, al-Khațīb al-Baghdādī explains that forged hadiths identified by one of the following indications: first, they contradict reason ( $a$ - 'uqul), for example, the statement that no Creator exists. Second, the hadith contradicts the al-Qur'ān, a widely established precedent of the Prophet (al-sunnah al-mutawätirah) or a report that the Muslim community has agreed upon (ijm $\bar{a})$ ) as being authentic. Third, the report conveys information that is so essential for Muslims that God would not allow it to be 
reported by a means other than one that assured its certainty. Finally, a report about some evident, unmistakable event that, if it had occurred, would have necessarily beendescribed via widely transmitted reports (J. A. C. Brown, 2008: 152) Ibn al-Qayyim also provide criteria that is adapted by many scholars after him. His criteria are, hadith that contradict the al-Qur'an; Second, hadith that contradict other authenticated hadith; Third, hadith that contradict the basics of the shari' 'ah; Fourth, hadith that have a severe, aggravated or grievous connotation; Fifth, hadith that contradict authenticated historical facts; Sixth, hadith that have illogical connotations; Seventh, hadith that contradict reality; and Eight, hadith that does that reflect the words of the Prophet (Ismail et al., 2014: 155).

\section{CONCLUSION}

Because of its important position as the second source of Islamic teachings, hadith has been subject of study by Muslim scholars since the era of the Companion. After the widespreading of hadith forgery following the fitnah, Muslim scholars have developed method to determine authentic hadiths from the forged ones. Their method is called 'ulüm al-hadith that is consists of isnād and matn criticism. Despite the critics of many modern scholars that traditional 'ulüm al-hadīth only cares about isnād, it has been proven that matn criticism has played important rule in hadith authentication since the early period. The important role of matn criticism is to find the 'illah and shädh in the matn.

\section{REFERENCES}

A'z̧amī, M. M. (1977). Studies in Hadìth Methodology and Literature. Kuala Lumpur: The Other Press.

Amin, K. (2005). The Reliability of the Traditional Science of Hadith: A Critical Reconsideration. Al-Jami'ah: Journal of Islamic Studies, 43(2), 255-281.

Brown, J. A. (2009). Did the Prophet Say It or Not? The Literal, Historical, and Effective Truth of Hadiths in Early Sunnism. Journal of the American Oriental Society, $129(2), 41-78$.

Brown, J. A. C. (2008). How We Know Early Hadīth Critics Did Matn Criticism and Why It's So Hard to Find. Islamic Law and Society, 15(2), 143-184.

Burton, J. (1994). An introduction to the Hadīth. Edinburgh: Edinburgh University Press.

Coulson, N. J. (1983). European Criticism of Hadtth Literature. In et. al. Beeston (Ed.), Arabic Literature to the End of the Umayyad Period. Cambridge: Cambridge University Press.

Goldziher, I. (1971). Muslim Studies (Muhammadanische Studied). Chicago Aldine Atherton: SUNY Press.

Hallaq, W. B. (1999a). A history of Islamic legal theories: An introduction to Sunn̄̄ ușūl al-fiqh. Cambridge: Cambridge University Press.

Hallaq, W. B. (1999b). The Authenticity of Prophetic Hadîth: A Pseudo-Problem. Studia Islamica, (89), 75-90.

Hasan, S. (1994). An introduction to the science of Hadith. London: Al-Quran Society.

Ibn Șalāḥ, T. al-D. U. ibn 'Abd al-R. (2002). Muqaddimah' Ulūm al-Hadīth. Dār alKutub al-'Ilmiyyah.

Ismail, T. M. S. T., Baru, R., Hassan, A. F., Bin Salleh, A. Z., \& Amin, M. F. M. (2014). 
The Matan and Sanad Criticisms in Evaluating the Hadith. Asian Social Science, 10(21), 152.

Kamali, M. H. (2014). A textbook of Hadith studies: authenticity, compilation, classification and criticism of Hadith. Kano Nigeria: Kube Publishing Ltd.

Khan, I. A. (2010). Authentication of Hadith: Redefining the Criteria. Herndon: IIIT.

Muhammad Zubair Shiddiqi. (1961). Hādith literature: its origin, development, special features and criticism. Calcutta: Calcutta University Press.

Muslim, ibn Ḥajjāj A. al-Ḥasan al-Q. A.-N. (n.d.). al-Musnad al-Ṣaḥīh al-Mukhtașar bi Naqli al- 'Adl 'an al- 'Adl Ilā Rasūlillāh. Beirut: Dār Iḥyā' al-Turāth.

Nabia Abbot. (1967). Studies in Arabic Literacy Papyri II Quranic Commentary and Tradition. Chicago: The Chicago of University Press.

Nabia Abbot. (1983). Hadith Literature: The Development of The Science of Hadith. In et. al. Beeston (Ed.), Arabic literature to the end of the Umayyad period. Cambridge: Cambridge University Press.

Philips, A. A. B. (2007). Usool Al-Hadeeth: the Methodology of Hadith Evaluation. Ridyadh: International Islamic Publishing House.

Schacht, J. (1950). The origins of Muhammadan jurisprudence. Oxford: The Clarendon Press. 